\title{
B2C E- COMMERCE FOR HOME APPLIANCE IN THE BRAZILIAN MARKET: A COST EFFICIENCY INVESTIGATION THROUGH A DEA-OCT MODEL
}

Isotilia Costa Melo ${ }^{1}$, Paulo Nocera Alves Junior, Tatiana Kimura Kodama, Karoline Arguelho da Silva, Mirian Wawrzyniak Chimirri, Daisy Aparecida do Nascimento Rebelatto Universidade de São Paulo - USP, São Paulo, (Brasil)

\section{ARTICLE DETAILS}

\section{Article history:}

Received: 9 July 2019

Accepted: 31 March 2020

Available online May: 01 th 2020

\section{Double Blind Review System}

Scientific Editor

Ilan Avrichir

\section{Key words}

E-commerce

Retail

Data Envelopment Analysis (DEA)

Optimal Control Theory (OCT)

Inventory Management

\begin{abstract}
Objective: to investigate the cost efficiency of inventory management for publicly home appliance retail companies in the Brazilian market that operate, among other channels, with B2C (Business-to-Costumer) and discuss the possible impacts of ecommerce on inventory management.

Method: the first step, construction of a descriptive summary of Magazine Luiza and seven other competitors; the second step, analysis of the optimal cost efficiency of companies' inventory management, through an integrated and dynamic model of Data Envelopment Analysis (DEA) and Optimal Control Theory (OCT). Amounts declared in the Quarterly Financial Statements between the fourth quarter of 2010 and the second quarter of 2018 were considered.

Main Results: the discovery of best practices and the fact that, despite its extraordinary appreciation, Magazine Luiza was not a reference in inventory management and its costs during the analyzed period as a whole.

Relevance/Originality: this article is an initial step to address the lack of studies on e-commerce for emerging markets and inventory management and its costs for ecommerce.

Methodological Contributions: the proposition of a methodology that can be used by other researchers to assess the cost efficiency of inventory management and the impact of e-commerce, highlighting best practices.
\end{abstract}

\section{Introduction}

Electronic e-commerce has received much attention since the 1990s due to the advent of new information and communication technologies (ICT) such as the internet -, which have given rise to new forms of business and new relationships between customers and suppliers (Mokhtarian, 2004). In Brazil, a significant fact was the rise of the stock price of the company Magazine Luiza (a retailer/e-retailer), which valued from $\mathrm{R} \$ 1.79$ (in January 2016) to $\mathrm{R} \$$ 136, 19 (in September 2018), i.e. a valuation of 7,608 $\%$ in 33 months, according to the data retrieved from Economática software (and corrected by inflation). The company attributes its success to the strategic plan for innovation in e-commerce and digital culture (MGLU3, 2018). Although the increasing interest in the e-commerce and market valuation phenomena, there are still few studies focused on operational aspects, especially in developing markets (Giuffrida,
Mangiaracina, Perego, \& Tumino, 2017; Sharma, Luk, Cardinali, \& Ogasavara, 2018).

For example, in the research field of performance measurement, jointly analyzing publications of Stochastic Frontier Analysis (SFA) and Data Envelopment Analysis (DEA) from 1978 until 2012, Lampe \& Hilgers (2015) concluded DEA is the preferred technique in Operational Research (OR) and SFA in Economic research fields, though the authors did not mention 'retail', 'e-commerce' or 'inventory' among the 23 most influential application areas of the tools. On the side of the OR research field, Huang, Li, \& Yu (2019) applied a multi-stage DEA model for investigating the most appropriate inventory allocation single-period strategy of the chain stores of a Canadian fast-fashion company. Basu \& Nair (2014) proposed an SFA model as a decision-support tool for multi-period inventory management in markets of high demand volatility 
such as fashion goods and technological products. Analyzing a sample of public retail companies in the US, Chuang, Oliva, \& Heim (2019) applied another SFA model for investigating the associations between inventory leanness and operational efficiency, under the moderating roles of firm size and demand uncertainty. Although relevant for the investigation field, none of the above mentioned investigated the impacts of e-commerce, operations in developing markets or integration of optimization with efficiency measurement.

Given the presented context, we aimed to draw a descriptive profile of a sample of public retail companies that operate in the Brazilian home appliance market (between the fourth quarter of 2010 and the second quarter of 2018 and competitors of Magazine Luiza) through, among other channels, B2C (Business-to-Costumer) ecommerce, focusing on measuring and understanding the companies' optimal inventory cost efficiency. Assuming the philosophical worldview of pragmatism (problem-centered and real-world practice-oriented), due to the novelty of the theme and the scarcity of data for the Brazilian market, we adopted a convergent mixed-method approach, which means the qualitative and qualitative analyses were performed in parallel and both results interpreted jointly (Creswell \& Creswell, 2018).

Regarding the structure of the paper, after a section of Qualitative Methodology - a narrative summary with the characteristics and news related to the evaluated companies -, the section of Quantitative Methodology states the steps for data collection in the Economática database, the details of the econometrical analysis, and the adopted nonparametric linear mathematical model, highlighting its main characteristics: the dynamic integration of DEA (Data Envelopment Analysis) - OCT (Optimal Control Theory) model for optimization, efficiency, evaluation, and comparison of the inventory control systems.

The section of Results and Discussions examines the DEA-OCT model based on the narrative summary and the section of Conclusions indicates that, despite its extraordinary market valuation and successful implementation of big data analysis strategies for increasing business profitability, Magazine Luiza is yet not a reference in the management of inventory costs when compared to its peers.

\section{Literature Review}

Measuring performance can be divided into financial (through approaches that exclusively use direct accounting data, such as SFA - Stochastic Frontier Analysis) or non-financial (through approaches that can incorporate non-financial measures, such as DEA - Data Envelopment Analysis) (Dyckhoff \& Souren, 2020). Lampe \& Hilgers (2015) summarized the differences between DEA and SFA into five categories: elements, algorithm, consideration of noise, function form/input-output relation, and factor weights. Although there are methods of SFA that allow multiple inputs and multiple outputs simultaneously, SFA models are generally assumed one output and multiple inputs. On the other hand, DEA models are usually used with multiple outputs and inputs, that can be qualitative or quantitative measures.

Additionally, according to Olesen \& Petersen (2016), SFA requires the specification of a functional form and explicitly accommodates noise, under restrictive assumptions, usually including just one specific inefficiency distribution, but sometimes it violates the purpose of the efficiency analysis, while DEA measures the efficiency score neither requiring the specification of a functional form in the deterministic model, nor the specification of the inefficiency distribution. On the end, DEA can be applied to anything that can be linearized, depending on the goal of the analysis and the overview of the general problem context (Olesen \& Petersen, 2016). Once SFA results can be extrapolated to a population, it usually requires a bigger sample than DEA (which results in a conditioned to the units of the sample).

Regarding e-commerce, Yang, Shi, \& Yan (2016) applied two-stage DEA to measure the website efficiency (first step) and the economic efficiency (second step) of public Chinese and American companies, which business model operate exclusively through online marketplaces (click-toclick). An online marketplace is (or online ecommerce marketplace) is a type of e-commerce platform where product or service information is provided by multiple third parties, whereas transactions are processed by the marketplace operator (usually, the retailer). For example, Magazine Luiza is a retailer originated from physical store chains that also operates, among other channels, with an online marketplace (brick-to-click), while Mercado Livre is a company that exclusively 
operates through an online marketplace (click-toclick). Operating through an online marketplace is considered mandatory for all e-commerce companies in Latin America (Emarketer, 2017).Tian et al. (2018), when strategically analyzing the e-commerce model of the marketplace, attested that, from the perspective of efficiency, it is recommended to consider the costs related to the inventory, storage, and transport system. The authors refer to these three costs jointly, as order-fulfillment costs. For classifying retails that operate through more than one channel, Beck \& Rygl(2015) proposed a binary taxonomy that considers the interaction through the point of view of the interaction customer and the point of view of the integration of the retailer's operation. The classification is divided into Multi-, Cross-, and Omnichannel Retailing, and subdivided into nine categories (from I to IX). For example, a retailer (such as Magazine Luiza) that offers services for customers such as "reserve online and collect instore (Retira na Loja)" is referred to overall as a CrossChannel Retailer. However, a retailer that does not provide a Cross-Channel service within its own physical store can also be categorized as CrossChannel Retailer, for example, when costumers take shoes in Carrefour's supermarkets, that they previously bought online through Dafiti's online marketplace (Exame, 2018).

Through the binary taxonomy, it is mandatory to classify Retailing from the point of view of the customer. For example, in Multichannel Retailing, the customer cannot trigger interaction, while in Multichannel, the customer can trigger partial interaction and/or the retailer can control partial integration no fat least two channels or all channels widespread at that time.

In other words, in the example or Retira na Loja from Magazine Luiza, if the customer can purchase merchandise from an online marketplace and return it to a physical store (instead of mailing it, for example), this would be classified as a 'Cross-Channel Retailer' and a 'Cross-Channel Retailing - Category III' since from the customer's viewpoint the channels partially interact. A DEA model would be able to integrate such qualitative classification as inputs or outputs (depending on the objective and methodological procedures). When analyzing exclusively the website performance, authors are limiting their analysis of e-commerce to the customer viewpoint. On the other hand, not considering ecommerce and channels interaction. Liu, Gong, Zhu,
\& Zhang (2018) applied a DEA model for investigating the efficiency of 124 global retailers and Huang, Li, \& Yu (2019) applied a multi-stage DEA model for investigating the most appropriate inventory allocation of store chains.

Alves Junior (2018) developed many integrated models of OCT (Optimal Control Theory) and DEA (Data Envelopment Analysis) for calculating the optimized efficiency over time, when the system has variables related to each other, as is the case of inventory control. That is, the inventory of a period $t$ is a result of the inventory of the previous period ( $t$ 1) minus the demand of $t$. Additionally, the proposal of Alves Junior (2018) extends the variational model, also analyzing production and demand. The DEA-OCT model also can assume the Variable Returns to Scale (VRS) as in the BCC model (Banker, Cooper, \& Charnes, 1984) and other models, when changes in the inputs do not lead to proportional changes in the outputs as if it was under Constant Returns to Scale (CRS).The OCT part of the model obtains the dynamically optimal storage functions, while the DEA part measures the relative efficiencies of the analyzed units. In the DEA literature, these units are called DMU (Decision Making Units).

Alves Junior (2018) applied a model to 647 of several sectors in South and North America, each company represents a DMU. The Brazilian retailers Magazine Luiza, Americanas.com and B2W were part of the sample of Alves Junior (2018). The three were inefficient in considering the final rank for the period from 2010 to 2016, thought Magazine Luiza had some efficiency quarters between 2013 and 2014. Alves Junior (2018) investigated the retail sector as a whole, comparing several countries simultaneously, without focusing on e-commerce specifically.

The DEA tool, by measuring relative efficiency among DMUs, is very sensitive to the sample selection. Therefore, it is recommended to keep in mind an overview of the entire investigated system and the main objective of the analysis for choosing the right sample, as well as testing many configurations before discuss and interpret the results (Cook, Tone, \& Zhu, 2014).

In summary, we believe there is a lack of an integrative methodology that measures efficiency considering both viewpoints (the customer interaction and of integration of the retailer's operation). We believe DEA would be one of the most appropriate tools for measuring the integrated 
performance, once it permits the integration of financial measures and qualitative evolutions at once, and it permits us to work with smaller samples than other statistical tools. As an initial contribution, we are proposing a qualitative investigation (focused on e-commerce and customer interest) and a quantitative investigation (an application of the DEAOCT model for the companies' performance).

\section{Qualitative Methodology: Narrative Summary}

The selection of the sample of companies was based on the official statement to shareholders of Magazine Luiza: "The main competitors of the Company are Mercado Livre, B2W, Via Varejo, Máquina de Vendas, Walmart, Carrefour, among others" (MGLU3, 2018, p.99). Máquina de Vendas was excluded from the analysis because it is not a public company. On the other hand, two companies not mentioned were added: Amazon and Americanas.com. The first one due to its worldwide relevance (EMARKETER, 2017) and the second because its operations are closely related to those of B2W (BTOW3, 2018; LAME4, 2018).

In this way, we read the official statement from 2017 of the following companies: Magazine Luiza, Mercado Livre, B2W, Via Varejo, Walmart, Carrefour, Americanas.com, and Amazon. To write the narrative summary, our interest was in the information related to the strategies of inventory and distribution networks for attending e-commerce. Also, if applicable, we sought news in the general media about related events cited in the documents. We also collected the companies' marketplace rank position at Alexa. Alexa is a leading provider of global web metrics, such as website popularity, user engagement, load time and related links. Table 1 summarizes the eight analyzed companies, the respective codes which they will be referred to during this text, their online marketplaces and their global position in Alexa's rank. Once Walmart Brazil closed its online marketplace in 2019 (Canaltech, 2019), it was not possible to retrieve previous rank positions in Alexa

Table 1 Analyzed companies and their online marketplaces

\begin{tabular}{llll}
\hline Company & Code & Online Marketplace & Alexa \\
\hline Magazine Luiza & MGLU3 & magazineluiza.com.br & $\# 1,494$ \\
\hline Amazon Brazil & AMNZ & amazon.com.br & $\# 640$ \\
\hline Walmart Brazil & WMT & marketplace.walmart.com.br & - \\
\hline Mercado Livre & MELI & mercadolivre.com.br & $\# 154$ \\
\hline Carrefour Brazil & CRFB3 & carrefour.com.br & $\# 5,312$ \\
\hline B2W & BTOW3 & submarino.com.br & $\# 2,364$ \\
\hline Americanas & LAME4 & americanas.com.br & $\# 550$ \\
\hline & & casasbahia.com.br & $\# 3,130$ \\
Via Varejo & VVAR4 & pontofrio.com.br & $\# 7,521$ \\
\hline
\end{tabular}

\section{Quantitative Methodology: Data Analysis and DEA-OCT Model}

The current section is divided into three subsections: Data Extraction, for presenting the data collection (variables, period, and source); Data analysis, presenting a statistical analysis for supporting the evidences of the relevance of the variables in DEA-OCT model; Discrete-time DEA-OCT model, showing the mathematical formulation of the model used for measuring the efficiency of the companies of interest.

\subsection{Data Extraction}

The data were retrieved from Economática software, considering the quarterly statements in dollars, since they are companies from different countries. The São Paulo Stock Exchange (B3) officially endowed the International Financial Reporting Standards (IFRS) in 2010. Therefore, the target period was from the last quarter of 2010 to the second quarter of 2018.

The data collected were the cost of products sold and inventory for the application of the model for the analysis of cost management efficiency and net operating revenue, for comparison and deepening of the discussion on the results. The data was deflated 
B2C E-commerce for Home Appliance in the Brazilian Market: A Cost Efficiency Investigation Through a DEA-OCT Model

(based on IPCA - Broad Consumer Price Index - from the fourth quarter of 2010 on), according to the instructions of IPEA (2020). For the sake of replicability, Table 2 shows the descriptive statistics of the variables that were effectively used in the DEAOCT model.

Table 2 Descriptive statistics of the data used in the model DEA-OCT.

\section{Cost of Products Sold (in million dollars)}

\begin{tabular}{l|ccccc}
\hline DMU & Obs. & Average & Std. Dev. & Min. & Max. \\
\hline MGLU3 & 31 & 1.43 & 0.67 & 0.44 & 2.67 \\
\hline BTOW3 & 31 & 1.12 & 0.57 & 0.34 & 2.27 \\
\hline VVAR4 & 31 & 3.66 & 1.61 & 0.92 & 8.07 \\
\hline MELI & 31 & 0.13 & 0.14 & 0.00 & 0.68 \\
\hline WMT & 31 & 217.55 & 100.87 & 78.18 & 373.40 \\
\hline AMNZ & 31 & 38.8 & 24.68 & 7.61 & 111.93 \\
\hline CRFB3 & 7 & 7.16 & 3.84 & 3.00 & 12.10 \\
\hline LAME4 & 31 & 2.28 & 1.12 & 0.80 & 4.26 \\
\hline & \multicolumn{5}{c}{ Inventory (in million dollars) } \\
\hline DMU & Obs. & Average & Std. Dev. & Min. & Max. \\
\hline MGLU3 & 31 & 0.50 & 0.00 & 0.30 & 0.67 \\
\hline BTOW3 & 31 & 0.37 & 0.00 & 0.23 & 0.54 \\
\hline VVAR4 & 31 & 1.18 & 0.24 & 0.67 & 1.62 \\
\hline MELI & 31 & 0.00 & 0.00 & 0.00 & 0.00 \\
\hline WMT & 31 & 44.17 & 3.57 & 36.33 & 51.50 \\
\hline AMNZ & 31 & 7.97 & 3.60 & 2.89 & 16.05 \\
\hline CRFB3 & 7 & 1.45 & 0.00 & 1.28 & 1.51 \\
\hline LAME4 & 31 & 0.95 & 0.14 & 0.72 & 1.26 \\
\hline
\end{tabular}

\subsection{Econometrics Analysis}

A correlation was made to investigate the iteration strength among variables. To strengthen the evidence that the variables used in the DEA model are relevant, a linear regression was executed.

The proposed model for linear regression is described in Equation 1:

$\log (\text { net operating income })_{i t}=\alpha_{i}+$ $\beta_{1} \log (\mathrm{CPV})_{\text {it }}+\beta_{2} \log (\Delta \text { Inventory })_{\text {it }}+\varepsilon_{\text {it }}$

(1)

In which log(net operating income $)_{\text {it }}$ is the log of the net operating income of each company $i$ in each quarter t. $\alpha_{i}$ is the specific effect of each company. $\log (C P V)_{i t}$ and $\log (\Delta \text { Inventory })_{\text {it }}$ are the logs of the cost of the product sold and of the variation of the inventory for each company and each quarter; and $\varepsilon_{\text {it }}$ is the template error.

For choosing the effect of the model, we ran the Hausman Test (Chmelarova, 2007; Hausman, 2015) at MatLab. Table 3 shows the results of the test. As it does not reject the null hypothesis, both methods (random or fixed effects) are adequate.

The chosen research method is the fixed-effect model, which has the advantage of controlling the particular characteristics of each company that does not vary over time. 
Table 3 Results of Hausman test.

\begin{tabular}{l|c|c}
\hline Variables & $\begin{array}{c}(1) \\
\text { Radom effect }\end{array}$ & Fixed effect \\
\hline log_CPV & $0.999^{* * *}$ & $1.002^{* * *}$ \\
\hline & $(0.00477)$ & $(0.00478)$ \\
\hline log_Inventories_variation & -0.000789 & -0.000402 \\
\hline Constant & $(0.00256)$ & $(0.00253)$ \\
& $0.624^{* * *}$ & $0.610^{* * *}$ \\
Observations & $(0.0854)$ & $(0.0614)$ \\
\hline R-squared & 454 & 454 \\
Number of ID & & 0.990 \\
\hline
\end{tabular}

Standard errors in parentheses

*** $p<0.01, * * p<0.05, * p<0.1$

\subsection{Discrete time DEA-OCT model}

The discrete-time model of Alves Junior (2018) minimizes production and inventory costs to calculate allocative efficiency through the period of interest. The output is demand; the input is production, and the intermediate variable is the inventory.

Costs are considered as the objective function. A variational constraint of the OCT is added to describe the relationship among demand, production, and inventory.
The cost of products sold is CPV. Inventory costs are divided into two periods: initial (CEI) and final (CEF). CEl is between $\mathrm{t}=0$ and $\mathrm{t}=\mathrm{T}-1$, i.e., the inventory of from the period before the first quarter (equal to the initial of the first quarter) until the second-to-last period (equal to the initial of the last quarter). For this reason, it is not possible to calculate the efficiency during the first and the last quarter of the retrieved data. CEF corresponds to the inventory between $t=1$ and $t=T$, i.e., the inventory from the first until the last quarter. The cost of the produced product (CCP) is calculated as CPP $=\mathrm{CEF}-\mathrm{CEI}+\mathrm{CPV}$. The model is shown in Equation 2.

$$
\min _{c z_{0 t}^{-p} c z_{0 t}^{+p} c x_{0 t}^{p}} \frac{c z_{0 t}^{-p}+\sum_{t=1}^{\top} c z_{0 t}^{+p}+\sum_{t=1}^{\top} c x_{0 t}^{p}}{C E I_{01}+\sum_{t=1}^{\top} C E F_{0 t}+\sum_{t=1}^{\top} C P P_{0 t}}
$$

Subject to the constraints shown in Table 4.

Table 4 Constraints of the model DEA-OCT.

\begin{tabular}{|c|c|}
\hline Projection constraints of outputs & $\sum_{\mathrm{k}=1}^{\mathrm{z}} \mathrm{CPV} \mathrm{kt}_{\mathrm{kt}} \lambda_{\mathrm{kt}}-\mathrm{S}_{\mathrm{ykt}}^{+}=\mathrm{CPV} \mathrm{V}_{\mathrm{Ot}}, \mathrm{t}=1,2, \ldots, \mathrm{T}$ \\
\hline Projection constraints of inputs & $\sum_{\mathrm{k}=1} \mathrm{CPP}_{\mathrm{kt}} \lambda_{\mathrm{kt}}+\mathrm{S}_{\mathrm{xkt}}^{-}=\mathrm{Cx} \mathrm{x}_{\mathrm{Ot}}^{\mathrm{p}}, \mathrm{t}=1,2, \ldots, \mathrm{T}$ \\
\hline \multirow[t]{2}{*}{ Constraints to links } & $\sum_{\mathrm{k}=1} \mathrm{CEF}_{\mathrm{kt}}^{+} \lambda_{\mathrm{kt}}+\mathrm{S}_{\mathrm{zkt}}^{+}=\mathrm{Cz}_{\mathrm{Ot}}^{+\mathrm{p}}, \mathrm{t}=1,2, \ldots, \mathrm{T}$ \\
\hline & $\sum_{\mathrm{k}=1}^{2} \mathrm{CEI} \mathrm{kt}_{\mathrm{kt}}^{-} \lambda_{\mathrm{kt}}+\mathrm{S}_{\mathrm{zkt}}^{-}=\mathrm{Cz}_{\mathrm{Ot}}^{-\mathrm{p}}, \mathrm{t}=1,2, \ldots, \mathrm{T}$ \\
\hline Intermediate equality constraints & $\sum_{k=1}^{2}\left(\mathrm{CEF}_{k \mathrm{t}}^{+} \lambda_{k t}-\mathrm{CEI}_{k(\mathrm{t}+1)}^{-} \lambda_{k(t+1)}\right)+S_{z k t}^{+}-\mathrm{S}_{z k(\mathrm{t}+1)}^{-}=0 \mathrm{t}=1, \ldots, \mathrm{T}-1$ \\
\hline Variational control constraints & $C x_{0 t}^{p}-C z_{0 t}^{+p}+C z_{0 t}^{-p}=C P V_{0 t} t=1,2, \ldots, T$ \\
\hline Initial value constraints & $\mathrm{Cz}_{01}^{\mathrm{p}}=\mathrm{CEI}_{01}$ \\
\hline Scale constraints (variable return) & $\sum_{\mathrm{k}=1}^{\mathrm{z}} \lambda_{\mathrm{k}}=1, \mathrm{t}=1,2,3, \ldots, \mathrm{T}$ \\
\hline
\end{tabular}


Where:

$\mathrm{cz}_{\mathrm{Ot}}^{-\mathrm{p}}$ : projection of the total cost of the link (as input, initial inventory cost) in period $t$.

$\mathrm{Cz}_{\mathrm{Ot}}^{+\mathrm{p}}$ : projection of the total cost of the link (as output, final inventory cost) in period $t$.

$\mathrm{cx}_{0 \mathrm{t}}^{\mathrm{p}}$ : projection of the total cost of the inputs in period $\mathrm{t}$. $\mathrm{CEI}_{01}$ : initial cost of inventory, at the beginning of the period under analysis (equal to the cost of final inventory of the previous period $t-1$ ).

$\mathrm{CEF}_{\mathrm{Ot}}$ : final cost of inventory at the end of the period under analysis.

$\mathrm{CPP}_{0 \mathrm{t}}$ : cost of produced product of the period under analysis.

CPV: cost of products sold.

$\lambda_{\mathrm{kt}}$ : contribution of $\mathrm{k}$-th DMU to the DMU under analysis.

$\mathrm{S}_{\mathrm{ykt}}^{+}$: slacks of the outputs (or links of the outputs).

$\mathrm{S}_{\mathrm{xkt}}^{-}$: slacks of the inputs (or link of the inputs).

In summary, the model is relevant for calculating efficiency, preventing the possibility of obtaining a projection that ignores the relationship among variables, since this relationship always happens in practice in inventory control systems.

Because, in the analyzed set, there may be companies of different sizes, we opted for a Variable Returns to Scale (VRS) model. The model was programmed and executed in MATLAB software.

We planned on running a single template configuration throughout the period (from 2010 to 2018). However, we had two limitations, Euronext stock data is not available in Economática and Carrefour Brasil (CRFB3) only opened its capital at B3 in 2016 and AMZN entered the Brazilian market in the same year. Hence the need to investigate another model, a possibility envisaged by Cook et al. (2014). Another interesting question was to investigate the impact of a transnational company that operates exclusively by the marketplace (MELI), in comparison to the others.

In this way, we executed six configurations of models: (1) all companies, except CRFB3 and AMZN, 2011-2018; (2) all companies except CRFB3 and AMZN, 2017-2108 (to investigate changes in the most recent period); (3) all companies except CRFB3, AMZN and MELI, 2017-2108 (to investigate the impact of MELI); (4) all companies except CRFB3 and MELI, 2017-2108 (to investigate AMZN's entry); (5) all companies except CRFB3, 2017-2108 (to investigate the entry of AMZN and MELI jointly); (6) all companies, including CRFB3, 2017-2108 (to investigate the efficiency of CRFB3 management, along with all available competitors, after its re-entry into e-commerce).

\section{Results and Discussions}

\subsection{Descriptive Summary}

This section presents a brief historical summary of the companies of interest. In the end, Table 5 compiles the most relevant events regarding ecommerce. Considering the global relevance of the companies' online marketplace in Alexa rank, the order is Mercado Livre, Americanas, Amazon Brazil, Magazine Luiza, B2W, Via Varejo, Carrefour, and Walmart.

\subsubsection{Mercado Livre}

Mercado Livre (or Mercado Libre in Spanish) is an Argentine transnational publicly traded company (incorporated in the US) that operates exclusively through marketplaces dedicated to e-commerce and online auctions. It was founded in 1999. The company's shares are sold on the stock exchange Nasdaq under the code MELI (MELI, 2018).

According to E-Commerce News, (2018a), Mercado Livre operates and owns a single CD in Brazil, the company announced a $200 \%$ expansion of the built area in 2018. According to E-Commerce News (2018b), the company announced the launch of Mercado Envio Flex, which allows marketplace suppliers to use multiple delivery modes for their sales, including walking and cycling, to enable the delivery of products on the same day of purchase. Initially, this option is only available for the city of São Paulo.

\subsubsection{Americanas and B2W}

B2W is a Brazilian retail company focused on ecommerce. The company emerged in 2006, from the merger of Americanas.com (a physical and digital retail company) with Submarino (a digital retail company) (BTOW3, 2018). B2W shares are traded on B3 under the code BTOW3. The stocks of Americanas.com, the controller of B2W, are traded on B3 under the code LAME4 and LAME3. The fact that the shares are traded under more than one code means that Americanas.com does not belong to the 
Novo Mercado (NM), a differentiation for companies with high corporate governance standards (BM\&F Bovespa, 2018).

B2W may share distribution infrastructure with Americanas.com and the latter uses the B2W marketplace for its online sales. The logistics strategies of $\mathrm{B} 2 \mathrm{~W}$ are described in the official statement of Americanas.com and not of B2W. LAME4 (2018) describes that Americanas.com owned 838 PSs in December 2013 and inaugurated its fourth DC in the same year. BTOW3 (2018) describes that all B2W DCs are leased, until December 2017, the company had 11 DCs and 200 own and partner operating centers dedicated to digital platform operations.

In 2013 and 2014, B2W Digital acquired the two ecommerce specialized carriers in Brazil (Click-Rodo and Direct). In 2016, it established an operational agreement with Vialog, the leading e-commerce delivery carrier in the South region. As a result of these movements, B2W Fulfillment (warehousing, distribution and customer service) was created. B2W Fulfillment is currently responsible for delivering 98\% of orders from B2W Digital sites. To support the growth of marketplace vendors, in March 2017 B2W Entrega was launched, a platform that operates and controls the deliveries of suppliers using the marketplace (BTOW3, 2018).

\subsubsection{Amazon Brazil}

Amazon is a US transnational publicly traded ecommerce company, founded under its name in 1994. Its shares are traded on the NASDAQ stock exchange under the code AMZN (AMZN, 2018).

According to EXAME (2017), the logistics structure of Amazon in Brazil is different from other countries. Amazon entered the Brazilian market (for other physical products besides books) in 2016 (Exame, 2017), and it is studied as a reference in e-commerce and logistics innovation (Boysen, Koster, \& Weidinger, 2018; Tian, Vakharia, Tan, \& Xu, 2018).

Abroad, Amazon has carriers and distribution centers (DCs) that house suppliers' products, so that Amazon's customers can receive their sales in tight due time. In Brazil, Amazon uses a unique leased DC (LDC) and outsourced transportation companies. Furthermore, Amazon opened its marketplace after its major competitors had already consolidated theirs.

\subsubsection{Magazine Luiza}

Magazine Luiza is a family-owned company, founded in 1957. As early as 1992, Magazine Luiza pioneered its first e-commerce model, called Lojas Eletrônicas. The sales were made through multimedia terminals in the shops, consisting of vendors who guided their customers, and there were no products on display or inventory. In 1996, despite being a privately held company, Magazine Luiza released its first externally audited financial statement, a requirement only for public companies. In June 2011, Magazine Luiza ended the IPO process at B3, its shares are traded under the code MGLU3 (MGLU3, 2018).

In 2017, Magazine Luiza's digital channels jointly site, mobile apps, and marketplace - accounted for $30 \%$ of total sales and $61 \%$ growth considering the same period of 2016 as a baseline. In 2017, the company also acquired the technology startup Donatelo Desenvolvimento de Software e Market Digital Ltda. (known by the name Integra Commerce), specialized in the integration and management of the relationship between suppliers and marketplaces. The main objective of the acquisition was to accelerate the execution of the development strategy of a profitable marketplace (MGLU3, 2018). In 2018, Magazine Luiza acquired the technology startup applied to logistics Logbee, which is a platform that manages the express delivery of light products, made daily by several suppliers (MGLU3, 2018).

Magazine Luiza has a unique and integrated system of corporate services and logistics. This system consists of more than 1,500 carriers, 716 conventional physical stores (CPSs), 141 virtual stores (VSs), 10 distribution centers (DCs) and a single shared service center (SSC). According to MGLU3 (2018), since the carriers already supply the PSs, the implementation of services related to e-commerce, such as the Retira Loja-purchasing mode that enables the customer to withdraw the online purchased product directly in the PSs, practically does not entail incremental costs.

\subsubsection{Via Varejo}

Via Varejos came from the merger between Casas Bahia and Pontofrio in 2009, promoted by the Pão de Açúcar Group, which is controlled by the Casino Group, a French holding. The stocks of Via Varejo are traded on B3 under the codes VVAR3, VVAR4, and 
VVAR11 (VVAR4, 2018). This means that Via Varejo does not belong to NM.

Among the company's goals are the unification of service and the integration of customer service and physical stores (VVAR4, 2018, p.173). The company is proud to have the greatest number of PSs in its segment, 975 (VVAR4, 2018, p. 70), served by 15 leased DCs (VVAR4, 2018, p. 80).

As a general rule, the freight from suppliers to the distribution center is paid by suppliers. The freight from the distribution center or warehouse to stores is paid by Via Varejo. The freight cost for deliveries to the customer is paid by Via Varejo. And a service fee is charged to the customer. The transportation of products is carried out by own transporters and contracted carriers. In 2016, Via Varejo had more than 800 own vehicles destined for the company's deliveries, and the percentage of deliveries made by third parties is approximately 90\% (VVAR4, 2018, p.80). The Via Varejo is the only company in the sector that also operates with own vehicles and the reasons for this are not clear in the official statement. After several consecutive losses, the company is in a process of restructuring and selling (InfoMoney, 2018).

\subsubsection{Carrefour Brazil}

Carrefour is a transnational open company of French origin. The Carrefour group was founded in 1958. Carrefour shares are traded on the Euronext stock exchange under the code CA and also on B3 under the code CRFB3 (CRFB3, 2018).

According to CRFB3 (2018), Carrefour has 373 PSs in Brazil, located in all Brazilian states and the Federal District, which are served by 17 strategically located DCs.

In Brazil, Carrefour inaugurated its first virtual store in 2010 (E-Commerce News, 2010). In 2012, the company decided to close its e-commerce operation for restructuring it (E-Commerce News, 2012). Carrefour only resumed e-commerce in 2017 with the launch of a digital platform for the sale of food products and soon after, making it possible, for the first time in Brazil, to sell food and non-food products on the same platform (E-Commerce News, 2018c).

Besides this, the company Bling (business management system) announced its integration with the Carrefour marketplace in July 2018 (E-Commerce News, 2018a). In May of the same year, the Bling company had already joined the Walmart marketplace (E-Commerce News, 2018) and in March the Amazon's (E-Commerce News, 2018b).

According to the Paulista Supermarket Association (APAS, 2010), among the innovations in the supply chain of Carrefour, we highlight the technology of inventory management by voice command. According to the Brazilian Society of Retail and Consumer Affairs (SBVC, 2017), to meet online shopping, the Carrefour network inaugurated its first dark store. A dark store is a warehouse full of products, where pickers pick and order products according to online orders. It functions as a minidistribution center for online shopping (Benedictus, 2014).

\subsubsection{Walmart Brazil}

Walmart is a US-listed transnational corporation founded under this name in 2008. As a department store, the company was founded in 1962 under the name Wal-mart. Walmart shares are traded on the New York Stock Exchange (NYSE) under the code WMT (WMT, 2018).

Walmart launched its marketplace in Brazil in December 2017 (Reuters, 2017). Walmart Brazil has maintained two separate companies (including with distinct headquarters) for the management of sales in physical stores and the management of ecommerce. These two companies were consolidated into a single one in 2017 (E-Commerce News, 2017).

According to Walmart Brasil (2018), the company is a benchmark for its ability to manage and innovate in its supply chain through the intensive use of information technology. In Brazil, Walmart has 21 DCs and 543 PSs. Its network covers the South, Southeast, Northeast regions, and the state of Mato Grosso do Sul, in the Center-West region. 
Table 5 Summary of main events of e-commerce.

\begin{tabular}{|c|c|c|c|c|}
\hline Company & Code & Business Model & Historical of e-commerce & Source \\
\hline Magazine Luiza & MGLU3 & brick-to-click & $\begin{array}{l}\text { In 1992, MGLU3 had it is the first trial } \\
\text { withe-commerce. } \\
\text { In 2016, MGLU3 launched its strategy } \\
\text { named "Digital Transformation". }\end{array}$ & (MGLU3, 2018) \\
\hline Amazon Brazil & AMNZ & click-to-click & $\begin{array}{l}\text { In 2016, AMNZ entered in Brazil selling } \\
\text { all physical products (not only books). }\end{array}$ & (EXAME, 2017) \\
\hline Mercado Livre & MELI & click-to-click & In 1999, it was found in Argentina. & (MELI, 2018) \\
\hline Walmart Brazil & WMT & brick-to-click & $\begin{array}{l}\text { In December 2017, WMT launched a } \\
\text { marketplace. } \\
\text { In May 2019, WMT gave up on e- } \\
\text { commerce. }\end{array}$ & $\begin{array}{l}\text { (Canaltech, 2019; } \\
\text { Reuters, 2017) }\end{array}$ \\
\hline Carrefour Brazil & CRFB3 & brick-to-click & $\begin{array}{l}\text { In 2010, CRFB launched e-commerce. } \\
\text { In 2012, CRFB3 closed e-commerce. } \\
\text { In 2017, CRFB3 launched its online } \\
\text { platform }\end{array}$ & $\begin{array}{l}\text { (E-Commerce News, } \\
\text { 2018c) }\end{array}$ \\
\hline B2W & BTOW3 & click-to-click & $\begin{array}{l}\text { In 2006, the company emerged from } \\
\text { the merger of Americanas.com with } \\
\text { Submarino (a digital retail company). }\end{array}$ & (BTOW3, 2018) \\
\hline Americanas & LAME4 & brick-to-click & In 1999, LAME4 started selling online. & (LAME4, 2018) \\
\hline Via Varejo & VVAR4 & brick-to-click & $\begin{array}{l}\text { In 2008, VVAR4 restructured to invest } \\
\text { in strategies for e-commerce. The } \\
\text { operations of all subsidiary brands are } \\
\text { concentrated in one company. }\end{array}$ & (VVAR4, 2018) \\
\hline
\end{tabular}

\subsection{Efficiency Results}

The first step was to verify the results of the statistical analysis, to understand the relevance of the variables of the DEA-OCT model to the financial results of the companies. The results for linear regression can be seen in Table 6 . The results were significant. As expected, the inventory had a negative relation (-0.0266) with net operating revenue and cost of product sold, a positive relation (0.979).

Table 6 Fixed Effect Model

\begin{tabular}{lc}
\hline Variables & Revenue \\
\hline & \\
\hline log_CPV & $0.979^{* * *}$ \\
& $(0.00863)$ \\
log_Inventories_variation & $-0.0266^{* * *}$ \\
\hline & $(0.00342)$ \\
\hline Constant & $1.033^{* * *}$ \\
& $(0.123)$ \\
Observations & 215 \\
\hline Number of ID & 8 \\
\hline R-squared & 0.985 \\
\hline
\end{tabular}

Standard errors in parentheses

$* * * p<0.01,{ }^{* *} p<0.05, * p<0.1$ 
B2C E-commerce for Home Appliance in the Brazilian Market: A Cost Efficiency Investigation Through a DEA-OCT Model

Then the next step was to investigate the net operating revenue to determine the size of the companies analyzed. Table 7 shows the descriptive statistics of this variable.

Table 7 Net operating revenue (in million dollars) of the analyzed companies

\begin{tabular}{l|ccccc}
\hline DMU & Obs. & Average & Std. Dev. & Min. & Max. \\
\hline MGLU3 & 31 & 2.05 & 0.96 & 0.00 & 3.75 \\
\hline BTOW3 & 31 & 1.47 & 0.75 & 0.00 & 3.00 \\
\hline VVAR4 & 31 & 5.22 & 2.75 & 1.32 & 11.20 \\
\hline MELI & 31 & 0.38 & 0.29 & 0.00 & 1.40 \\
\hline WMT & 31 & 290.59 & 134.85 & 104.19 & 500.34 \\
\hline AMNZ & 31 & 57.57 & 39.58 & 9.86 & 177.87 \\
\hline CRFB3 & 7 & 8.97 & 4.82 & 3.75 & 15.20 \\
\hline LAME4 & 31 & 3.26 & 1.61 & 1.11 & 6.10 \\
\hline
\end{tabular}

Table 7 shows that Mercado Livre (MELI) has the lowest revenue, while Walmart (WMT) has the greatest. The average revenue for all companies added up is $27.2 \%$ of WMT revenue. Excluding Amazon (AMNZ), the sum of the revenues is equivalent to $7.3 \%$ to that of the WMT. Thus, there are two large companies, WMT and AMZ and the others are small when compared to revenues. In this way, the VRS assumption was justified in the model. Table 8 shows the results of the six model configurations

Table 8 Results of the tested configurations for the DEA-OCT model

\begin{tabular}{|c|c|c|c|c|c|c|}
\hline & 1 & 2 & 3 & 4 & 5 & 6 \\
\hline & $(2011-2018)$ & \multicolumn{4}{|c|}{$(2017-2018)$} & $(2017-2018)$ \\
\hline $\begin{array}{l}\text { DMU } \\
\text { MGLU3 }\end{array}$ & $\begin{array}{c}\text { Efficiency } \\
0.9511\end{array}$ & 0.9488 & $\begin{array}{l}\text { Efficienc } \\
0.9949\end{array}$ & 0.9624 & 0.8944 & $\begin{array}{c}\text { Efficiency } \\
0.8903\end{array}$ \\
\hline BTOW3 & 0.9606 & 0.9776 & 1 & 1 & 0.9763 & 0.9641 \\
\hline LAME4 & 0.9186 & 0.9462 & 0.9525 & 0.9467 & 0.9409 & 0.9175 \\
\hline VVAR4 & 0.9877 & 0.9424 & 0.9475 & 0.8766 & 0.8654 & 0.8316 \\
\hline WMT & 1 & 1 & 1 & 1 & 1 & 1 \\
\hline MELI & 1 & 1 & - & - & 1 & 1 \\
\hline AMNZ & - & - & - & 1 & 1 & 1 \\
\hline CRFB3 & - & - & - & - & - & 0.9867 \\
\hline
\end{tabular}

Model 1 (Table 8) considers six companies from 2011 until 2018 and presents WMT and MELI as efficient. WMT is a much larger company than the others and has physical stores (therefore has more inventory), while MELI adopts the pure marketplace business model.

Although its failure in adopting a successful ecommerce strategy (Table 5), the WMT is efficient in all investigated models, possibly due to gain of scale and because online sales may not represent a great percentage of the company's revenues. MELI is also efficient in all models where it is considered $(1,2,5$, and 6). It is relevant that in the models where MELI is not considered ( 3 and 4), B2W (BTOW3, another company that adopts a pure marketplace business model) becomes an efficient DMU. This can mean a natural advantage of the marketplace mode to be efficient in inventory costs since this cost is passed on to suppliers. Though, that, however, the exclusive adoption of the marketplace is not the unique cause 
for efficiency, since companies that do not adopt it have also been efficient (or almost). Models 4 and 5 point out that whenever the AMNZ is considered, it is also among the efficient ones. Like MELI, AMNZ has a single distribution center in Brazil, i.e. they are companies with small territorial coverage in a country of continental extension. Restricted coverage can also be one of the causes of their efficiency.

Magazine Luiza (MGLU3) is the second most inefficient in Model 1, but its position goes up in Models 2 and 3, both referring to a more recent period and not considering (in the DEA-OCT samples) AMZN, Carrefour Brazil (CRFB3) and, in the case of Model 3, not considering MELI neither. Improving efficiency for recent periods can demonstrate the application of new management practices (after the adoption of the Digital Transformation strategy in 2016, as shown in Table 5). In that same period, MGLU3 is consistently more efficient than Via Varejo (VVAR4), which bankrupted. As the DEA part of the model measures the relative efficiency, it may be that the best (relative) performance of MGLU3 is due to the worse performance of VVAR4.

In Model 6, MGLU3 returns to the second most inefficient position and CRFB3 achieves a quasiefficient condition. However, unlike AMZN, CRFB3 is not a new player. Seeking a deeper investigation of the impact of CRFB3 in the available time frame, Table 9 shows the efficiency results of Model 9 per quarter.

Table 9 Results of Model 6 by quarter

\begin{tabular}{ccccccc}
\hline DMU & (2017-2018) & 1st 2017 & 2nd 2017 & 3rd 2017 & 4th 2017 & 1st 2018 \\
\hline MGLU3 & 0.8903 & 0.9316 & 0.9140 & 0.8999 & 0.8646 & 0.7053 \\
\hline BTOW3 & 0.9642 & 1 & 1 & 0.9702 & 0.9382 & 0.8673 \\
\hline LAME4 & 0.9176 & 0.9699 & 0.9807 & 0.8650 & 0.8962 & 0.7951 \\
\hline WVAR4 & 0.8316 & 0.8224 & 0.8331 & 0.8280 & 0.8553 & 0.5768 \\
\hline WMT & 1 & 1 & 1 & 1 & 1 & 1 \\
\hline MELI & 1 & 1 & 1 & 1 & 1 & 1 \\
\hline AMNZ & 1 & 1 & 1 & 1 & 1 & 1 \\
\hline CRFB3 & 0.9868 & 0.9469 & 1 & 1 & 1 & 0.9338 \\
\hline
\end{tabular}

As seen in Table 9, WMT, MELI, and AMNZ remain efficient all quarters. CRFB3 presents 3 efficient quarters. This may demonstrate temporary difficulties in the process of implementation of good practices and in the resumption of e-commerce (first quarter of 2017, Table 5), or that, for some reason, the company faces difficulties in being efficient in the first quarters (for example, the inventory can be impacted by the previous quarter - Christmas sales).

It is interesting to remember that WMT, CRFB3, and AMZN have their marketplace strategy managed by the same company, Bling. Bling has been managing the AMZN's marketplace since the second quarter of 2017, the WMT's since the third and CRFB3's, since the third of 2018 (therefore, outside the analysis period).

As WMT and AMZN are permanently efficient, it will be interesting to see if the CRFB3 will achieve permanent efficiency too and how the management of Bling will contribute to this.

When comparing WMT with CRFB3, both are supermarkets and considered leaders of innovation in supply chain management, distribution network, and storage. It is important to remember that WMT is a larger company than CRFB3, though WMT has a smaller territorial scope, smaller distribution network, and fewer physical stores. This can mean a greater management challenge for CRFB3 and that CRFB3 may have better management practices so that it can be almost as efficient as WMT (in relative comparison). This possibility could be investigated with a case study.

BTOW3 was efficient in the first and second half of 2017 after that performance did not hold. Further investigation is needed to determine the cause. MGLU3 is more efficient only than VVAR3 in all periods. In the third quarter of 2017, MGLU3 is also slightly more efficient than LAME4. It is interesting to note that LAME4 and VVAR3 do not belong to the Novo Mercado, that is, they do not have a formal commitment to high standards of corporate governance. Suggesting that governance standards can also influence the efficiency of inventory cost 
management. Finally, we can understand that MGLU3 does not demonstrate a benchmark for optimized inventory cost management, although the extraordinary valuation of its shares.

\section{Conclusions}

We drew a narrative summary of the B2C ecommerce scenario for the Brazilian home appliance market, focusing on publicly traded companies that are competitors of Magazine Luiza. Additionally, we measured the cost inventory efficiency of the identified players.

For the current application, we found four factors that may be impacting efficiency. Three factors positively affect efficiency (in the studied samples and periods): (i) the adoption marketplace as an exclusive mode of selling; (ii) the culture of being innovative in supply chain management and distribution network; and (iii) the adoption of high standards of corporative governance.

One factor negatively affects the efficiency is territorial coverage. Though, the obstacles generated by huge distances can be overpassed by innovation and good management practices, as seen to be the case of Carrefour Brazil. Although its astonishing stock valuation, Magazine Luiza is not a benchmark for inventory cost efficiency. The findings also

\section{References}

Alves Junior, P. N. (2018). Gestão de estoque e eficiência dinâmica: Uma abordagem integrada entre Análise Envoltória de Dados (DEA) e Teoria do Controle Ótimo (OCT). Escola de Engenharia de São Carlos, Universidade de São Paulo. São Carlos.

AMZN. (2018). Annual Report. Retrieved from https://ir.aboutamazon.com/static-files/917130c5e6bf-4790-a7bc-cc43ac7fb30a

APAS. (2010). Carrefour adota comando de voz em centro de distribuição - APAS - Associação Paulista de Supermercados. Retrieved October 9, 2018, from http://www.portalapas.org.br/carrefour-adotacomando-de-voz-em-centro-de-distribuicao/

Banker, R., Cooper, A., \& Charnes, W. (1984). Some Models for Estimating Technical and Scale Inefficiencies in Data Envelopment Analysis. Management Science, 30(9), 1078-1092. pointed out the relevance of deep investigation about the management practices of Magazine Luiza, Carrefour Brazil, Walmart, and Mercado Livre.

For further steps of methodology development, we recommend the classification of selling channels of the companies of interest according to Beck \& Rygl (2015), incorporating, for example, sales through social media. For further applications, whether the data is available, it is recommended to study also small and medium companies, as well as privately held companies in general.

It is also suggested to improve the methodology by considering a probabilistic demand in a Chance Constrained DEA-OCT model, or overcoming the limitations of addressing stochastic aspects, as uncertainty and random noise, in a Dynamic Stochastic DEA-OCT model.

A practical limitation is the lack of data of important players acting globally and cross-border ecommerce companies from other countries that were not considered in the analysis, but they could have an impact even the companies analyzed in this paper.

We believe we successfully contributed with the literature, proposing a methodology that can be used by other researchers to evaluate the efficiency of inventory cost management and the impact of ecommerce on it, highlighting successful cases.

Basu, P., \& Nair, S. K. (2014). A decision support system for mean-variance analysis in multi-period inventory control. Decision Support Systems, 57(1), 285-295. https://doi.org/10.1016/j.dss.2013.09.012

Beck, N., \& Rygl, D. (2015). Categorization of multiple channel retailing in Multi-, Cross-, and OmniChannel Retailing for retailers and retailing. Journal of Retailing and Consumer Services, 27, 170-178. https://doi.org/10.1016/j.jretconser.2015.08.001

Benedictus. (2014). Inside the supermarkets' dark stores | Business | The Guardian. The Guardian. Retrieved from https://www.theguardian.com/business/shortcuts/2 014/jan/07/inside-supermarkets-dark-stores-onlineshopping

BM\&F Bovespa. (2018). Segmentos de listagem. Retrieved October 11, 2018, from http://www.bmfbovespa.com.br/pt_br/listagem/aco es/segmentos-de-listagem/novo-mercado/ 
Boysen, N., de Koster, R., \& Weidinger, F. (2018). Warehousing in the e-commerce era: A survey. European Journal of Operational Research, 0, 1-16. https://doi.org/10.1016/j.ejor.2018.08.023

BTOW3. (2018). Formulário de Referência 2018. Retrieved from https://ri.b2w.digital/informacoesaos-investidores/outros-arquivamentos-cvm

Canaltech. (2019). Walmart encerra seu ecommerce no Brasil. Retrieved March 5, 2020, from https://canaltech.com.br/e-commerce/walmartencerra-seu-e-commerce-no-brasil-138991/

Chmelarova, V. (2007). The Hausman test, and some alternatives, with heteroskedastic data. Retrieved from https://digitalcommons.Isu.edu/gradschool_disserta tions/936

Chuang, H. H. C., Oliva, R., \& Heim, G. R. (2019). Examining the Link between Retailer Inventory Leanness and Operational Efficiency: Moderating Roles of Firm Size and Demand Uncertainty. Production and Operations Management, 28(9), 2338-2364. https://doi.org/10.1111/poms.13055

Cook, W. D., Tone, K., \& Zhu, J. (2014). Data envelopment analysis: Prior to choosing a model. Omega (United Kingdom), 44, 1-4. https://doi.org/10.1016/j.omega.2013.09.004

Creswell, J. W., \& Creswell, J. D. (2018). Research Design: Qualitative, Quantitative, and Mixed Method Approaches (5th ed.). SAGE Publications.

CRFB3. (2018). Formulário de Referência. Retrieved from https://www.grupocarrefourbrasil.com.br/

Dyckhoff, H., \& Souren, R. (2020). Data Envelopment Methodology of Performance Evaluation (pp. 47-82). https://doi.org/10.1007/9783-030-38732-7_3

E-Commerce News. (2010). Loja virtual brasileira do Carrefour servirá de modelo para toda a América Latina - E-Commerce News. Retrieved October 9, 2018, from

https://ecommercenews.com.br/noticias/lojavirtual-brasileira-do-carrefour-servira-de-modelopara-toda-a-america-latina/

E-Commerce News. (2012). Carrefour diz: Até mais, e-commerce - E-Commerce News. Retrieved October 9, 2018, from https://ecommercenews.com.br/noticias/lancament os/carrefour-diz-ate-mais-e-commerce/

E-Commerce News. (2017). Walmart vai integrar loja física e e-commerce no Brasil - E-Commerce News. Retrieved October 9, 2018, from https://ecommercenews.com.br/noticias/lancament os/walmart-vai-integrar-loja-fisica-e-e-commerceno-brasil/

E-Commerce News. (2018a). Bling anuncia integração com marketplace do Carrefour - ECommerce News. Retrieved October 9, 2018, from https://ecommercenews.com.br/noticias/parceriascomerciais/bling-anuncia-integracao-commarketplace-do-carrefour/

E-Commerce News. (2018b). Bling passa a integrar com Amazon - E-Commerce News. Retrieved October 9, 2018, from https://ecommercenews.com.br/noticias/parceriascomerciais/bling-passa-a-integrar-com-amazon/

E-Commerce News. (2018c). Carrefour lança serviço inédito de e-commerce alimentar e não alimentar na mesma plataforma - E-Commerce News. Retrieved October 9, 2018, from https://ecommercenews.com.br/noticias/lancament os/carrefour-lanca-servico-inedito-de-e-commercealimentar-e-nao-alimentar-na-mesma-plataforma/

E-Commerce News. (2018d). Mercado Livre amplia em 200\% centro de distribuição em condomínio GLP - E-Commerce News. Retrieved October 5, 2018, from https://ecommercenews.com.br/noticias/parceriascomerciais/mercado-livre-amplia-em-200-centro-dedistribuicao-em-condominio-glp/

E-Commerce News. (2018e). Mercado Livre terá serviço de logística para entregas no mesmo dia - ECommerce News. Retrieved October 5, 2018, from https://ecommercenews.com.br/noticias/lancament os/mercado-livre-tera-aplicativo-de-logistica-paraentregas-no-mesmo-dia/

EMARKETER. (2017). A Brief Overview of the Global Ecommerce Market | eMarketer Retail. Retrieved October 5, 2018, from https://retail.emarketer.com/article/brief-overviewof-global-ecommercemarket/59690010ebd40005284d5cc5 
B2C E-commerce for Home Appliance in the Brazilian Market: A Cost Efficiency Investigation Through a DEA-OCT Model

Exame. (2018). Startup para substituir Correios capta $R \$ 1,2$ milhão pela internet | EXAME. Retrieved October 5, 2018, from https://exame.abril.com.br/pme/startup-parasubstituir-correios-capta-r-12-milhao-pela-internet/

EXAME. (2017). Agora sim a Amazon poderá dizer que "chegou" ao Brasil | EXAME. Retrieved October 5, 2018, from https://exame.abril.com.br/revistaexame/agora-sim-a-amazon-podera-dizer-quechegou-ao-brasil/

Giuffrida, M., Mangiaracina, R., Perego, A., \& Tumino, A. (2017). Cross-border B2C e-commerce to Greater China and the role of logistics: a literature review. International Journal of Physical Distribution \& Logistics Management, 47(9), 772-795. https://doi.org/10.1108/IJPDLM-08-2016-0241

Hausman, J. A. (2015). Specification tests in econometrics. Applied Econometrics, 38(2), 112-134. https://doi.org/10.2307/1913827

Huang, H., Li, S., \& Yu, Y. (2019). Evaluation of the allocation performance in a fashion retail chain using data envelopment analysis. The Journal of The Textile Institute, 110(6), 901-910. https://doi.org/10.1080/00405000.2018.1532376

InfoMoney. (2018). Via Varejo tem prejuízo de R\$ 79 milhões, mas uma má notícia pode ser boa InfoMoney. Retrieved October 29, 2018, from https://www.infomoney.com.br/viavarejo/noticia/7 730847/via-varejo-tem-prejuizo-de-r-79-milhoesmas-uma-ma-noticia-pode-serboa?utm_source=newsletter\&utm_medium=email\& utm_campaign=nlminhasfinancas

IPEA. (2020). Transformação de séries macroeconômico. Retrieved March 5, 2020, from http://www.ipeadata.gov.br/iframe_transformacao. aspx?width $=1474$ \&height $=701$

LAME4. (2018). Formulário de Referência. Retrieved from http://bvmf.bmfbovespa.com.br/ciaslistadas/empresas-

listadas/ResumoEmpresaPrincipal.aspx?codigoCvm=80 87\&idioma=pt-br

Lampe, H. W., \& Hilgers, D. (2015, January 1). Trajectories of efficiency measurement: A bibliometric analysis of DEA and SFA. European
Journal of Operational Research. Elsevier. https://doi.org/10.1016/j.ejor.2014.04.041

Liu, J., Gong, Y. (Yale), Zhu, J., \& Zhang, J. (2018). A DEA-based approach for competitive environment analysis in global operations strategies. International Journal of Production Economics, 203, 110-123. https://doi.org/10.1016/j.ijpe.2018.05.029

MELI. (2018). Annual Report. Retrieved from http://investor.mercadolibre.com/staticfiles/7ec3a95a-553f-4802-ae80-a7f8cb6cb1d0

MGLU3. (2018). Formulário de Referência. Franca. Retrieved from https://ri.magazineluiza.com.br/listgroup.aspx?idCa nal=ZNbIHtomXIPEN1ssTVaUhQ $==\& a n o=2018$

Mokhtarian, P. L. (2004). A conceptual analysis of the transportation impacts of B2C e-commerce. Transportation, 31(3), 257-284. https://doi.org/10.1023/B:PORT.0000025428.64128. d3

Olesen, O. B., \& Petersen, N. C. (2016, May 16). Stochastic data envelopment analysis - A review. European Journal of Operational Research. Elsevier. https://doi.org/10.1016/j.ejor.2015.07.058

Reuters. (2017). Wal-Mart to integrate physical, online units in Brazil. Retrieved October 9, 2018, from https://www.reuters.com/article/us-walmart-brazilecommerce/wal-mart-to-integrate-physical-onlineunits-in-brazil-idUSKBN1DZ2G2

SBVC. (2017). Conheça a estrutura criada pelo Carrefour para vender alimentos online. Retrieved October 9, 2018, from http://sbvc.com.br/carrefourestrutura-alimentos-online/

Sharma, P., Luk, S. T. K., Cardinali, S., \& Ogasavara, M. H. (2018, May 1). Challenges and opportunities for marketers in the emerging markets. Journal of Business Research. Elsevier Inc. https://doi.org/10.1016/j.jbusres.2018.01.065

Tian, L., Vakharia, A. J., Tan, Y. R., \& Xu, Y. (2018). Marketplace, Reseller, or Hybrid: Strategic Analysis of an Emerging E-Commerce Model. Production and Operations Management, 27(8), 1595-1610. https://doi.org/10.1111/poms.12885 
VVAR4. (2018). Formulário de Referência. Retrieved http://ri.viavarejo.com.br/default_pt.asp?idioma $=0$ \&conta $=28$

Walmart Brasil. (2018). Logística e transportes » Centros de Distribuição (CDs). Retrieved October 9, 2018, from http://www.mediagroup.com.br/host/walmart/2015 $/ p t / 16 . h t m$
WMT. (2018). Annual Report. Retrieved from http://s2.q4cdn.com/056532643/files/doc_financial s/2018/annual/WMT-2018_Annual-Report.pdf

Yang, Z., Shi, Y., \& Yan, H. (2016). Scale, congestion, efficiency and effectiveness in ecommerce firms. Electronic Commerce Research and Applications, 20, 171-182. https://doi.org/10.1016/j.elerap.2016.07.003

\section{About Authors}

Isotilia Costa Melo - Escola de Engenharia de São Carlos da Universidade de São Paulo - EESC/USP, São Paulo, (Brasil). E-mail: isotilia@gmail.com Orcid id: https://orcid.org/0000-0002-4210-9325

Paulo Nocera Alves Junior - Escola Superior de Agricultura Luiz de Queiroz da Universidade de São Paulo ESALQ/USP, São Paulo, (Brasil). E-mail: pjnocera@yahoo.com.br Orcid id: https://orcid.org/0000-0002-8906-788X

Tatiana Kimura Kodama - Escola de Engenharia de São Carlos da Universidade de São Paulo - EESC/USP, São Paulo, (Brasil). E-mail: kimura.tatiana@gmail.com Orcid id: https://orcid.org/0000-0002-8583-6469

Karoline Arguelho da Silva - Escola de Engenharia de São Carlos da Universidade de São Paulo - EESC/USP, São Paulo, (Brasil).E-mail: karoline.arguelho@usp.br Orcid id: https://orcid.org/0000-0001-9196-1939

Mirian Wawrzyniak Chimirri - Escola de Engenharia de São Carlos da Universidade de São Paulo - EESC/USP, São Paulo, (Brasil).E-mail: mirianwk@gmail.com Orcid id: https://orcid.org/0000-0003-2526-5454

Daisy Aparecida do Nascimento Rebelatto - Escola de Engenharia de São Carlos da Universidade de São Paulo EESC/USP, São Paulo, (Brasil). E-mail: daisy@sc.usp.br Orcid id: http://orcid.org/0000-0003-0611-1492 


\section{E-COMMERCE BC2 PARA ELETRODOMÉSTICOS NO MERCADO BRASILEIRO: UMA INVESTIGAÇÃO DA EFICIÊNCIA DE CUSTO POR MEIO DE UM MODELO DEA-OCT}

Isotilia Costa Melo, Paulo Nocera Alves Junior, Tatiana Kimura Kodama, Karoline Arguelho da Silva, Mirian Wawrzyniak

Chimirri, Daisy Aparecida do Nascimento Rebelatto

Universidade de São Paulo - USP, São Paulo, (Brasil)

\begin{tabular}{l}
\hline DETALHES DO ARTIGO \\
\hline Histórico do Artigo: \\
Recebido: 9 de Julho de 2019 \\
Aceito: 31 de Março de 2020 \\
Disponível online: 01 de maio de 2020 \\
Sistema de revisão “Double blind review” \\
Editor Científico \\
llan Avrichir \\
Palavras-chave: \\
E-commerce \\
Varejo \\
Análise Envoltória de Dados (DEA) \\
Teoria do Controle Ótimo (OCT) \\
Gestão de Estoque \\
\end{tabular}

RESUMO
Objetivo: investigar a eficiência de custo da gestão de estoque para empresas de
capital aberto varejistas de eletrodoméstico no mercado brasileiro que operam,
entre outros canais, com B2C (Business-to-Costumer) e discutir os possíveis
impactos do e-commerce na gestão de estoques.
Método: primeiro passo, construção de um sumário descritivo da Magazine Luiza e
outros sete competidores; segundo passo, análise da eficiência de custo ótima da
gestão de estoque das empresas, por meio de um modelo integrado e dinâmico de
Data Envelopment Analysis (DEA) e Optimal Control Theory (OCT). Foram
considerados valores declarados nos Demonstrativos Trimestrais entre o quarto
trimestre de 2010 até o segundo trimestre de 2018 .
Principais Resultados: descoberta das melhores práticas e do fato de que, apesar
da sua valorização extraordinária, Magazine Luiza não foi uma referência na gestão
de estoques e seus custos durante o período analisado como um todo.
Relevância/Originalidade: este artigo é um passo inicial para suprir a falta de
estudos sobre e-commerce para mercados emergentes e gestão de estoques e seus
custos para e-commerce.
Contribuiçães Teóricas / Metodológicas: proposição de uma metodologia que pode
ser usada por outros pesquisadores para avaliar a eficiência de custo da gestão de
estoques e o impacto do e-commerce, destacando as melhores práticas.




\section{COMERCIO ELETRÓNICO B2C PARA ELECTRODOMÉSTICOS EN EL MERCADO BRASILEÑO: UMA INVESTIGACIÓN DE EFICIENCIA DE COSTOS UTILIZANDO UM MODELO DEA-OCT}

Isotilia Costa Melo, Paulo Nocera Alves Junior, Tatiana Kimura Kodama, Karoline Arguelho da Silva, Mirian Wawrzyniak Chimirri, Daisy Aparecida do Nascimento Rebelatto Universidade de São Paulo - USP, São Paulo, (Brasil)

\section{HISTORIA DEL ARTÍCULO}

Historia del Artículo:

Recibido: 9 de Julio de 2019

Aceptado: 31 de Marcha de 2020

Disponible en línea: 01 de Mayo 2020

Double Blind Review System

Editor Científico

Ilan Avrichir

\section{Palabras-clave:}

Comercio electrónico

Minorista

Análisis Envolvente de Datos (DEA)

Teoría del Control Óptimo (OCT)

Gestión de Inventario

\begin{abstract}
RESUMEN
Objetivo: investigar la eficiencia de costos de la gestión de inventario para minoristas de electrodomésticos que venden sus productos en el mercado brasileño y operan con B2C (Business-to-Costumer); discutir los posibles impactos del comercio electrónico.

Método: primer paso, construcción de un resumen descriptivo de Magazine Luiza y otros siete competidores; segundo paso, análisis de la eficiência de costos óptima de la gestión de inventario de las empresas, a través de un modelo integrado y dinámico de Data Envelopment Analysis (DEA) y Optimal Control Theory (OCT). Se consideraron los montos declarados en los estados trimestrales entre el cuarto trimestre de 2010 y el segundo trimestre de 2018. Resultados Principales: descubrimiento de mejores prácticas y el hecho de que, a pesar de su apreciación extraordinaria, Magazine Luiza no fue una referencia en la gestión de inventario y sus costos durante el período analizado en su conjunto.

Relevancia / Originalidad: este artículo es un paso inicial para abordar la falta de estudios sobre comercio electrónico para mercados emergentes y gestión de inventario y sus costos para comercio electrónico.

Contribuciones teóricas / metodológicas: propuesta de una metodología que puede ser utilizada por otros investigadores para evaluar la eficiencia de costos de la gestión de inventario y el impacto del comercio electrónico, destacando las mejores prácticas.
\end{abstract}

Cite it like this:

Melo, I., Alves Junior, P., Kodama, T., Silva, K., Chimirri, M., \& Rebelatto, D. (2020). B2C E-commerce for Home Appliance in The Brazilian Market: A Cost Efficiency Investigation through a DEA-OCT Model. Internext, 15(2), 72-89. doi:http://dx.doi.org/10.18568/internext.v15i2.557 